\title{
Effect of Computer Assisted Instruction on the Achievement of Basic School Students in Pre-Technical Skills
}

\author{
Paul Dela Ahiatrogah \\ Centre for Continuing Education, \\ University of Cape Coast, Cape Coast, Ghana. \\ pauldela57@yahoo.com \\ Moses Bedwei Madjoub \\ Agogo College of Education, Agogo, Ghana \\ ekowbedwei@gmail.com \\ Brandford Bervell \\ Centre for Continuing Education, \\ University of Cape Coast, Cape Coast, Ghana. \\ b_brandford@yahoo.co.uk
}

Doi:10.5901/ajis/2013.v2n1p77

\section{Abstract}

The study compared the effects of Computer Assisted Instruction (CAI) on the achievement of Junior High School (J.H.S) students in Pre-Technical skills after exposing them to CAI and the traditional methods of instruction. The theoretical framework for the study is that people learn most things better through construction of computer games or multimedia composition rather than through traditional methods of directly teaching content. The study involved 59 students from two schools in Kumasi Metropolis. Twenty eight of the students formed the CAI group while 3Iformed the traditional group. Quasi-experimental design was used for the study. Structured pre-test and post-test achievement test with a reliability coefficient $\alpha=0.74$ and 0.75 respectively were used to collect data. The data was analyzed using Predictive Analysis Software (PASW) version I8. The study revealed that the CAI group performed better than the traditional method of instruction group. However, there was no statistically significant difference between the achievements levels of the two groups. It was recommended that CAI should be introduced in the teaching of Pre-Technical skills throughout the country.

Key words: Computer Assisted Instruction (CAI), Achievement, Intellectual capabilities, Computer laboratory

\section{Introduction}

In this present digital era, development in various aspects of computer technology has reached a stage beyond our imagination and expectations. Even though the computer has a lot of applications in various fields, one should not forget its applications in the field of education. It is very useful and helpful in the teaching and learning process, therefore computer literacy is very much needed for teachers as well as learners. The computer has created a revolution in education and the nature of learning process. It has great effect upon our educational system as such teachers should be in terms with the physical reality of 
the computers and learn how to take actual advantage of the computer's educational potential (Bennett 1999).

Computer knowledge can be stated as knowing about the various fundamental aspects of computers and the basic skills involved in the operations of computers. It also includes the applications of computer in teaching and learning processes (Timothy 2007). It is, therefore, heart-warming that Ghana has formally adopted the teaching and learning of Information and Communication Technology (ICT) in its pre-tertiary educational system. In this direction, students are expected to develop interest and use ICT for learning other subjects among other things (Curriculum Research and Development Division [CRDD] 2007). Moreover, teachers are also expected to teach with computers.

One mode through which computers can be used in the teaching and learning processes is the Computer Assisted Instruction (CAI) technology (Traynor 2003). Even though Salomon (as cited by Kankaanranta, 2005) has stated that the use of computer serves as a trigger for transformations and technology-enriched instructional innovations, which involve profound changes that affect the very nature of entire learning environments, research on the use and effectiveness of CAI vary (Cotton I99I; Ornstein and Levine 1995). Ornstein and Levine (1995) indicated that some researchers have revealed that CAI has been effective for short-term achievement gains such as quizzes, but not for long-term gains such as retention. Moreover, because the acquisition of computer hardware and educational software programs involves a considerable monetary investment, it is worthwhile that such statements are made based on empirical evidence (Cotton 199I).

Pre-Technical Skills was introduced in the curriculum of the then Junior Secondary School (J.S.S) in 1987 as a result of the new educational reform. As a compulsory subject, every J.S.S student was required to write an examination on it in the Basic Education Certificate Examination (BECE). Currently, with the introduction of the Junior High School (J.H.S) system, a new syllabus covering PreTechnical Skills, Home Economics and Visual Art has been introduced. This syllabus required students to select any one of the subjects for the BECE. Evidence from a study by Adamtey (2009) indicated that the reputation of Technical and Vocational Education has been low among Ghanaians because the youth believe that Technical and Vocational Education is for the academically limited students and people with physical disabilities. Furthermore, the practical nature of the Pre-Technical Skills subject accompanied with the abstract way in which it is taught in class instead of the workshop, has contributed to most Junior High School students showing little interest in the subject compared to interest shown in other subjects. Most government schools do not have workshops and tools to facilitate the teaching and learning of the Pre-Technical Skills subject.

Our position in this paper is that the introduction of CAI can enhance the practicality of PreTechnical Skills. The procedural method involved can be incorporated in the computer program to enable easy understanding of the subject and also make it interesting. It is assuring to note that a reasonable number of Ghanaian children of this $2 \mathrm{I}^{\text {st }}$ century, particularly those in the urban areas, are attracted to the use of computers and are thus acquiring various computer skills than before. Therefore, the development of Pre-Technical Skills software will not only enhance children's computer skills but also assist them to acquire technical knowledge to enhance their performance.

\section{I.I Theoretical and Conceptual frame work}

Constructivism provides an appropriate framework for educational technology. Based on the research of Seymour Papert (Co-founder of MIT's Artificial Intelligence and Media Labs, professor of Media Technology at MIT, and one of the world's foremost experts on the impact of computers on learning) and others, we are learning that computers are an appropriate medium to support active, interactive, and self-directed learning. Technology can allow students to work out their own learning strategies, develop 
different learning styles, express themselves and not only demonstrate, but also use their new knowledge in many different ways. Computers and the Internet facilitate constructivist practices by providing a medium for discovery and exploring larger worlds and giving students autonomy in using knowledge. Learning in a computational environment provides a context for learning in which there is an empowering sense of a student's own ability to learn anything he or she wants to know, with the gusto we only use to see when they played video games. The potential exists to bring back an enthusiasm for learning by shaping education to fit each student's approach to learning (Papert and Harel, I99I).

Papert believes that the fundamental fact about learning is that anything is easy if you can assimilate it to your collection of models. The understanding of learning must be genetic, it is internal; it comes from a personal, passionate interest. The "laws of learning" must be about how intellectual structures grow out of one another and about how, in the process, they acquire both logical and emotional form. Purpose is the key here. A computer's essence is its universality; its power to simulate because it can take on a thousand forms and can serve a thousand functions, it can appeal to a thousand tastes. Computers, as a medium, are flexible enough so that people, especially young people can each create for themselves something that is emotionally and intellectually stimulating (Papert 1980).

The Internet, as a code word for connectivity, is a radical transformation. Creating collaborative learning communities with students in one's own class and students from around the country and around the world can have a qualitative difference in their development. (Papert, 1996)

\section{I.2 Statement of the Problem}

As Ghana incorporates the use of computers in its pre-tertiary educational system (CRDD 2007), it is very necessary and important that the effects of the variety of computer usage are explored. This will help the nation to know and be assured that whatever technology they are bringing will have a positive effect on both teachers and students. It is therefore very necessary, that a study is conducted to examine the effectiveness of CAI, as against the traditional approach of teaching. CAI is new to our present educational system, in view of that little has been done to introduce it in technical educational programs. This is because most of the technical teachers are themselves new to the computer or used to the traditional method of teaching.

In most Junior High Schools (JHS) in Ghana, Pre-Technical Skills is one of the subjects that students dislike because of its practical nature (Adamtey 2009). The situation is even made worse since very little is being done in the development of Pre-Technical Skills software that will minimize or eliminate the abstract ways in which some teachers teach the subject due to lack of workshops.

The purpose of this research therefore was to examine the relation between the achievement levels of Junior High School students who are taught with CAI and those who are taught with the normal traditional method of teaching Pre-Technical Skills.

\section{Methods}

\section{I Research Design}

The research design used for this study was the quasi experimental design with a focus on Nonequivalent Groups Pre-test and Post-test since the study required the manipulation of the experimental variables. Also, because random assignment of subjects was not possible, already established intact groups were used. This design was chosen because it is very prevalent and useful in education. It provides reasonable control over most of the variables affecting internal and external validity. Furthermore, the groups involved may be different prior to the study (Mertens I998). 
The threats to the internal validity with this design are mortality and history. This did not prove to be a threat in this study, since the group sizes remained constant throughout, and the study was relatively short in duration. Furthermore, no event other than that of the experimental treatment occurred during the time between Pretest and the Posttest observation. This design is represented diagrammatically in Figure I.

FigureI. Non-equivalent Groups Pre-test and Post-test Design

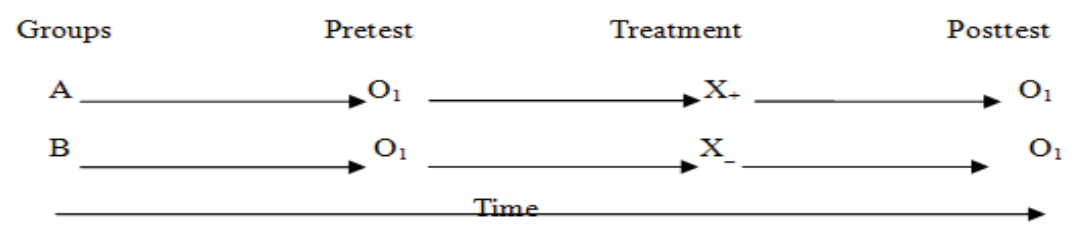

Figure I illustrates the Non-equivalent Groups of Pretest-Posttest. Two comparable groups were used in the order of $\mathrm{A}$ and $\mathrm{B}$ respectively. The two groups were initially given a Pretest $\left(\mathrm{O}_{\mathrm{I}}\right)$, afterwards, two different treatments $\left(\mathrm{X}_{+}\right)$and $\left(\mathrm{X}_{-}\right)$were administered to group $\mathrm{A}$ and $\mathrm{B}$. Finally, Posttest $\left(\mathrm{O}_{\mathrm{I}}\right)$ was conducted. The duration from the Pretest treatment to the Posttest of the experiment happened within a specified time.

\subsection{Population and Sample}

The population for the study comprised all JHS both private and public in Kumasi Metro, totaling 386 schools. However, the accessible population was IO schools where computers were available and accessible for students use (Education coordinator's report Kumasi Metropolitan, 2009), as well as those who have chosen from other options to study Pre-Technical Skills at JHS 2 in their various schools. Two schools Vicande and Shalom JHS were purposively selected out of the schools in Kumasi. This is because they are similar in academic rating and both had well equipped computer laboratories where each student had access to a computer.

Intact JHS 2 Pre-Technical Skills classes from the two schools were used for this research. Since it was morally wrong to withdraw some students from the class, all students in the classes concerned were involved. Shalom JHS 2 Pre-Technical Skills students were 28 in number out of which 13 were females and 15 were males. Vicande JHS 2 Pre-Technical Skills students were made up of I5 females and I6 males totaling 3I students. The total number of males involved in this research was 3I and that of females was 28. The sample size for the study therefore was 59 .

Vicande Junior High School was assigned the group where the traditional method of teaching was introduced (Traditional group). Whilst Shalom Junior High School was assigned to the group where CAI was introduced (CAI group).

\subsection{Instruments}

The instruments for the study were teacher made achievement test for the Pre-test and Post-test. The test items were based on Aggregates, Adhesives and Finishes which are the three major topics in Unit 2, Unit 3 and Unit 4 of the JHS Pre-Technical Skills syllabus. These topics have not been treated in the two schools prior to the study. The instrument had 30 multiple choice items with 10 items from each topic. To ensure the content validity of the test items, the tests were given to two experienced graduate Pre-Technical Skills teachers at the University of Education Winneba Kumasi and New Aboabo M/A 
JHS to critically review the content. Pilot testing of the instrument was conducted at Nigrition International School at Dechemso in Kumasi. The school was selected because it had a computer laboratory and also can be found in the first IO schools in the Kumasi metro analysis of basic education certificate examination result 2009.

Furthermore, to find the reliability of the instruments, scores obtained from the pilot testing of the test instrument were analyzed. The reliability coefficients alpha was computed using split half estimates Spearman-Brown prophecy formula. The pilot Pre-test and Post-test of the 30 test items revealed a reliability coefficient of 0.74 , and 0.75 respectively.

The CAI was developed using Microsoft office power point 2007. The Pre-Technical Skills software contains three major topics, with two sub topics each. The major topics were aggregates, adhesives and finishes. The lessons were made to last for 35 minutes to 70 minutes a section in other to fit into the JHS timetable. In developing the technical software, provision was made for introduction of the program, learner control, presentation of information, and ending the program.

To make sure that the CAI is free from problem before it is implemented, it was pilot tested in other to correct any unforeseen error before the start of the study. Pilot testing of the CAI was conducted at Saviour International School at Tanoso in Kumasi. The school was selected because it had a computer laboratory and also can be found in the first IO schools in the Kumasi metro analysis of basic education certificate examination result 2009.

\subsection{Data Collection Procedure}

\subsection{Treatment Plan}

The study was carried out in 3 phases, phase I pre-treatment assessment, phase 2 treatment package and phase 3 post-treatment assessments.

Phase I: Pre-treatment assessment: The pre- treatment assessment instrument made up of 30 test items on the selected Pre-Technical Skills topics was administered to the two groups, at their various schools to obtain a pre-test or a baseline data. The pre-treatment assessment lasted for I day.

Phase 2: Treatment package: Different methods of teaching were adopted in the 2 schools. The treatment for CAI group involved the use of CAI in teaching the selected Pre-Technical Skills topics namely Aggregate, Adhesives and Finishes. Traditional group benefited from the Traditional method of teaching the same topics listed, which one of the researchers personally delivered. Participants were exposed to 70 minutes of teaching the selected Pre-Technical Skills topics two times in a week for five weeks.

Phase 3: Post-treatment assessment: At the end of the treatment, the researchers re-administered the assessment instrument on the selected Pre-Technical Skills topics to the schools in one day. This was done to ascertain the effects of the two treatments on the participants. Scores obtained from the two schools provided the final post-test data

\subsection{Data Analysis}

The Pre-test and Post-test were scored objectively and data obtained was entered into SPSS program, which helped to prepare tables for interpretation. The entire hypothesis was tested with Analysis of Covariance (ANCOVA).

This procedure was used since the Pre-test scores obtained from the CAI and Traditional groups were not the same, therefore, there was the need to adjust the Post-test scores based on the initial differences (Tabachnick and Fidell, 200I). Furthermore, since random assignment of subjects was not 
possible, these groups may differ on a number of attributes (Mertens 1998). The use of ANCOVA reduced some of these differences and the scores on the Pre-test are treated as covariate to control for pre-existing differences between the groups (Pallant 2005). The achievements of the groups were also compared based on the mean deviation of the test scores of the CAI and Traditional groups. Finally, all the significant differences were compared to a significant level of 0.05 .

\section{Results and Discussion}

\section{Hypothesis I}

Ho There is no statistically significant difference between the academic achievements of students taught by Computer-assisted instructions and those taught with the Traditional method of teaching.

Table I: One-way Analysis of Covariance (ANCOVA) on Differences in Performance Between the Traditional and CAI Methods of Teaching Pre-Technical Skills

\begin{tabular}{lccccc}
\hline Source & $\begin{array}{c}\text { Type III sum } \\
\text { of squares }\end{array}$ & df & Mean Square & F & Sig. \\
\hline Corrected Model & $379.95^{a}$ & 2 & 189.98 & 109.95 & .00 \\
Pretest & 367.95 & I & 367.95 & 212.95 & .00 \\
Group & 43.14 & I & 43.14 & 24.97 & .00 \\
Error & 96.76 & 56 & 1.73 & & \\
Total & 25333.00 & 59 & & & \\
\hline
\end{tabular}

Significant at .05 level; $\mathrm{df}=\mathrm{I} \& 56 ;$ critical $\mathrm{P} \leq .05$

The data presented in Table I shows that a calculated F-value of 24.97 resulted in the difference in performances between the Traditional method of teaching and the CAI. This calculated F-value of 24.97 is statistically significant since the significant level of .00 is less than .05 of alpha significance level, at I and 56 degree of freedom. This implies that there is a significant difference between the Traditional and CAI methods of teaching Pre-Technical Skills.

Hence the null hypothesis Ho stating "There is no statistically significant difference between the academic achievements of students taught by Computer-assisted instructions and those taught with the Traditional method of teaching" was rejected.

This finding supports the constructivist perspective which emphasizes the active role of the learner in building understanding, and making sense of information presented to him (Roblyer and Edwards 2000; Hsu Chen and Hung, 2000; Good and Brophy, 1990). This is so because the students taught by the CAI, through knowledge discovery and interaction with the CAI showed a significant difference in their academic achievement. Furthermore, previous studies done by Morse (I99I); Kuchler (1998) and others, which explored the effectiveness of CAI in teaching Science and Mathematics, found that students who received instructions through CAI achieved more than those who studied in a conventional environment. It can therefore be concluded that students achievement in Pre-technical skill, did significantly improved due to the use of the CAI.

\section{Hypothesis 2}

$\mathrm{H}_{0}$ : There is no significant difference between the CAI and Traditional groups on their achievement in Aggregates, a topic in Pre-Technical Skills. 
Table 2: One-Way Analysis of Covariance (ANCOVA) on differences in Performance on Aggregates between the Traditional and CAI Groups

\begin{tabular}{lccccc}
\hline Source & $\begin{array}{c}\text { Type III sum } \\
\text { Of squares }\end{array}$ & df & $\begin{array}{c}\text { Mean } \\
\text { Square }\end{array}$ & F & Sig. \\
\hline Corrected Model & $9.36^{a}$ & 2 & 4.68 & I.04 & $.36 \mathrm{I}$ \\
Pretest & $6.4 \mathrm{I}$ & $\mathrm{I}$ & $6.4 \mathrm{I}$ & $\mathrm{I} .42$ & .24 \\
Group & 3.63 & $\mathrm{I}$ & 3.63 & .806 & .37 \\
Error & 252.30 & 56 & $4.5 \mathrm{I}$ & & \\
Total & 2933.00 & 59 & & & \\
\hline .05 level; df = I \& 56; Critical P $\geq .05$ & & & &
\end{tabular}

Significant at .05 level; $\mathrm{df}=\mathrm{I} \& 56$; Critical $\mathrm{P} \geq .05$

The data presented in Table 2 summarizes the outcome of the ANCOVA analysis on the differences in performance on Aggregates between the Traditional and CAI groups. It compared the Pre-test and Post-test aggregate scores obtained by the CAI group and the Traditional groups. The data shows that a calculated F-value of .806 resulted in statistically no significant difference in performance between the Traditional group and the CAI group. This calculated F-value of .806 is statistically not significant since, the significant level of . 37 is greater than the alpha significant level of .05, given I and 56 degrees of freedom. This implies that there is no significant difference between the academic achievements on aggregates, between the CAI group and the Traditional group. Hence, the null hypothesis Ho stating "There is no significant difference between the CAI and Traditional groups on their achievement on aggregates, a topic in Pre-Technical Skills." was retained.

The findings from Table 2 in one way or the other confirms the constructivists believe since it can be concluded that the students in the CAI group who interacted with only the Pre-Technical Skills software on the computer, obtained the needed academic information on Aggregates required to place them at pair, with the Traditional group who were taught by a teacher. It also supports Bennett (I999) statement that, "if schools were wealthy enough to afford hardware for each pupil, finding and retaining qualified teachers would be impossible. Another aspect is that computers, offer personal advantage of attention and instruction for each student" (p I05). In this instant, Bennett (1999) in his time, will have preferred computers to teachers had it not been the cost of computers. In some cases they can produce the same output, as that of paid teachers.

\section{Hypothesis 3}

Ho: There is no significant difference between the CAI and Traditional groups on their achievement in Adhesives, a topic in Pre-Technical Skills

Table 3: One-Way Analysis of Covariance (ANCOVA) on differences in Performance on Adhesives between the Traditional group and CAI group

\begin{tabular}{llllll}
\hline Source & $\begin{array}{l}\text { Type III sum } \\
\text { of Squares }\end{array}$ & df & $\begin{array}{l}\text { Mean } \\
\text { Square }\end{array}$ & F & Sig. \\
\hline Corrected Model & $17.63^{a}$ & 2 & 8.81 & 2.00 & .145 \\
Pretest & 17.18 & I & I7.18 & 3.89 & .053 \\
Group & 1.00 & I & 1.00 & .23 & .64 \\
Error & 247.22 & 56 & 4.42 & & \\
Total & 3198.00 & 59 & & & \\
\hline
\end{tabular}

Significant at .05 level; $\mathrm{df}=\mathrm{I} \& 56 ;$ Critical $\mathrm{P} \geq .05$ 
The data presented in Table 3 summarizes the outcome of the ANCOVA analysis on the differences in performance on Adhesives between the Traditional and CAI groups. It compared the Pretest and Post-test Adhesives scores obtained by the CAI group and the Traditional groups. The data shows that a calculated F-value of .23 resulted in statistically no significant difference in performance between the Traditional group and the CAI group. This calculated F-value of .23 is statistically not significant since, the significant level of .64 is greater than the alpha significant level of .05, given I and 56 degrees of freedom. This implies that there is no significant difference on the academic achievements in adhesives, between the CAI group and the Traditional group. Hence, the null hypothesis Ho stating "There is no significant difference between the CAI and Traditional groups on their achievement in Adhesives, a topic in Pre-Technical Skills," was retained.

Daramola and Asuquo (2006) conducted a similar research on "Effect of Computer Assisted Instructional Package on Secondary School Students' Performance in Nigeria”. They concluded by not finding any significant difference in the performance of students who were exposed to individualized CAI and those that were taught using conventional method of instruction. The findings of Table 3 can be concluded that the CAI method of instruction can produce similar results as the Traditional method instruction in some subjects, of which Adhesives in Pre-Technical Skills is no exception.

\section{Hypothesis 4}

Ho: There is no significant difference between the CAI and Traditional groups on their achievement in Finishes, a topic in Pre-Technical Skills.

Table 4: One-Way Analysis of Covariance (ANCOVA) on differences in Performance on Finishes between the Traditional group and CAI group

\begin{tabular}{llllll}
\hline Source & $\begin{array}{l}\text { Type III sum } \\
\text { of squares }\end{array}$ & df & Mean Square & F & Sig. \\
\hline Corrected Model & $15.77^{2}$ & 2 & 7.87 & 1.60 & $.2 \mathrm{I}$ \\
Pretest & $\mathrm{I} 4.62$ & $\mathrm{I}$ & 14.62 & 2.97 & .09 \\
Group & 2.09 & $\mathrm{I}$ & 2.09 & .43 & .52 \\
Error & $275.4 \mathrm{I}$ & 56 & 4.92 & & \\
Total & 2976.00 & 59 & & & \\
\hline
\end{tabular}

Significant at .05 level; $\mathrm{df}=\mathrm{I} \& 56 ;$ Critical $\mathrm{P} \geq .05$

The data presented in Table 4 shows that a calculated F-value of .43 resulted in statistically no significant difference in performance between the Traditional group and the CAI group. This calculated F-value of .43 is statistically not significant since the significant level of .52 is greater than .05 of alpha significance level, given I and 56 degree of freedom. This implies that there is no significant difference on the academic achievements in finishes, between the CAI group and the Traditional group. Hence, the null hypothesis Ho stating "There is no significant difference between the CAI and Traditional groups on their achievement in Finishes, a topic in Pre-Technical Skills", was retained.

The finding of Table 4 agrees with Mclean (1996) opinion that CAI provides student with an alternative to classroom settings. Since in this case, it can be concluded that a CAI meant to teach finishes will produce the same impact as a teacher using the usual Traditional method to teach.

\section{Conclusion}

The results of this study demonstrated that CAI was also an effective mode for teaching Pre-Technical 
Skills. The results were also in consonance with results of many studies demonstrating the effectiveness of CAI for better student's achievement, in science and mathematics as done by Brophy (1999); Carter (2004) and Bayrakter (2000). It can therefore be concluded that a relationship exists between the uses of a computer Assisted Instruction and achievement of students in Pre-Technical Skills. Furthermore, CAI can be used as an alternative to the Traditional method of teaching the various topics in PreTechnical Skills

It can be concluded that this study has provided strong evidence of the usefulness of CAI in teaching and learning of Pre-Technical Skills, it will therefore be very helpful if attention is paid to this study. By using CAI, procedural, methodical and abstract things can be brought home to the understanding of the Pre-technical students and more so make learning very interesting and easy.

\section{Recommendations}

In the light of the findings revealed, the following recommendations were made:

\section{I Recommendations for Government}

I. Computer Assisted Instruction centre's should be built in all communities, and equipped with learning software's. This will occupy student's free times anytime they are outside the school.

2. Modernize basic school classrooms by equipping every classroom with a computer and a projector to facilitate active learning.

3. Take steps to help reduce the prices of computers by either reducing taxes or offering incentives to computer and educational software importers.

\subsection{Recommendations for Ghana Education Service}

I. Should select experts of Computer Assisted Instruction from Ghana and send them to countries where this mode of instruction is utilized. This will enable them upgrade their knowledge and make meaningful impact on their return.

2. Computer Assisted Instruction should be introduce in the curriculum of Colleges of Education. This will enable the teacher- trainees to prepare their own software to teach various subjects.

3. The basic school curriculum should be designed such that it will allow students to construct their learning activities based on their own interpretation of what is needed.

\subsection{Recommendations for Teachers}

I. They should always be around to supervise students when they are using computers to learn. This is because most students will in turn do something else with the computer rather than learning.

2. They should avail themselves to new technologies such as Computer Assisted Instruction in other to be upgrade with time.

\section{Suggestions for further research}

I. Having attested to the efficacy of computer Assisted Instruction on academic achievements of senior high students, more of this and varied kinds must be researched into advanced levels of 
our education in all subjects especially mathematics, science, vocational and technical programmes.

\section{References}

Adamtey, K. S. (2009). Vocational / Technical Education in Ghana: Problems and Remedies. International Journal of home Economic Research, 20(I), I89-197.

Bayraktar, S. (2000). A Meta-analysis on the Effectiveness of Computer-Assisted Instruction In Science Education. Doctoral Dissertation Ohio University. [Online] Available: http:// www. Ocle.com (April 5, 2010)

Bennett, F. (Ed.). (1999). Computers as Tutors Solving the Crisis in Education. Sorasota: Feben Inc.

Brophy, A. K. (1999). Is Computer Assisted Instruction Effective in the Science Classroom? Unpublished M.Sc. Thesis, California State University, Dominguez Hill.

Carter, M. B. (2004). An Analysis and Comparism of the Effects of Computer. Assisted Instruction Versus Traditional Lecture Instruction, Students attitudes and achievement in a college remedial Mathematics Course. Ph.D. Thesis, Temple University Philadelphia. [Online] Available : http://www.templeuniversityphiladephia/the/pub/329y7 (May 20, 2010)

Cotton, K. (I99I). Computer-Assisted Instruction. School Improvement Series: U. Can Use. [Online] Available : www.nwrel.org/scpd/sirs/5/ culO.html_(May 20, 2008)

Curriculum Research and Development Division. (CRDD) (2007) "Teaching Syllabus for Information and Communication Technology. (Senior High School) Accra: Ministry of Education, Youth and Sports", [Online] Available: http:// ejite .isu. edu/ volumeI No2/ Lunts.htm.pii (January 8, 2010)

Daramola, F. O., \& Asuquo, E. N. (2006). Effect of Computer Assisted Instructional Package on Secondary School Students' Performance In Introductory Technology. In Ilorin, Nigeria, The Nigeria Journal of Educational Media and Technology. I2(I), pp. 20-26.

Education Coordinator's Report (2009). Computers in basic schools in Kumasi Metropolis. Kumasi : Hampton Press.

Good, T. L. \& Brophy, J. E. (1990). Educational psychology: A realistic approach. (4th ed.).White Plains, NY: Longman.

Hsu, J. J. F., Chen, D., \& Hung, D. (2000). Learning Theories and IT: The Computer as a Tutor. In Williams, M. D. (Ed.) (2000) Integrating Technology into Teaching and Learning Concepts and Applications, $\left(2^{\text {nd }} e d.\right)$ Singapore: Prenice Hall Inc.

Kankaanranta, M. (2005). International Perspectives on the Pedagogically Innovative Uses of Technology. Human Technology, I, (2), III-II6.

Kuchler, J. M. (1998) "The Effectiveness of Using Computers to Teach Secondary School (Grades 6 -I2) Mathematics: A Meta-Analysis". (On-line) Ph.D Dissertation, University of Lowell. [Online] Available : http://www.OCLC.com (May 20, 2010)

Mertens, D. M. (1998). Research Methods in Education and Psychology. London : SAGE Publications.

Morse, R. H.(I99I). Computer use in Secondary Education. ERIC Clearing House on Information Resources. ED33I489

Pallant, J. (2005) SPSS Survival Manual Second Edition (Electronic Version).[Online] Available : www.openup.co.uk/spss p. 269 (January 20, 2010)

Roblyer, M. D. (1988). The Effectiveness of Micro-Computers in Education: A Review of the Research from 1980-1987. Technological Horizons in Education Journal, 12, 85-89.

Roblyer. M. D. (1989). The Impact of Micro-Computer Based Instruction on Teaching and learning: A Review of Recent Research. ERIC Clearing house on Information resources. ED3I5063

Roblyer, M. D., \& Edwards J. (2000). Integrating Educational Technology into Teaching. (2 $2^{\text {rd }}$ ed.). Upper Saddle River : Prentice Hall Inc.

Timothy T. (2007). Assessing the computer attitudes of students: An Asian perspective. Computer in Human Behaviour. [Online) Available: http://www.compu.edu./aa.fac/cc. html. (April I2, 2010) 